\title{
Management of a Spontaneous Dissection of the Right External
}

\section{Artery}

Majdi Gueldich*, Héla Ben Jemâa, Saif Hadhri, Nawel Hchaichi, Aymen Damak, Imed Frikha

Department of cardiovascular surgery, Habib Bourguiba university hospital. University school of medecine of Sfax. University of sfax. Tunisia

*Corresponding author: Majdi Gueldich, Department of cardiovascular surgery, Habib Bourguiba university hospital. University school of medecine of Sfax. University of sfax. Tunisia.

Received date: June 17, 2021; Accepted date: August 03, 2021; Published date: Augusł 09, 2021

Citation: Majdi Gueldich, Héla Ben Jemâa, Saif Hadhri, Nawel Hchaichi, Aymen Damak, Imed Frikha. (2021) Management of a Spontaneous Dissection of the Right External Artery. J. Archives of Medical Case Reports and Case Study, 4(5); DOI:10.31579/2692-9392/070

Copyright: ( 2021 Majdi Gueldich, This is an open access article distributed under the Creative Commons Attribution License, which permits unrestricted use, distribution, and reproduction in any medium, provided the original work is properly cited.

\section{Abstract}

Introduction: Isolated spontaneous iliac artery dissection is a rare event that is usually linked to connective disorders. There is no established consensus yet on treatment modality.

Case report: we report the case of a 44 years old patient with no history of vascular diseases or trauma who was admitted in our institution for a spontaneous dissection of the right external iliac artery.

Conclusion: management of spontaneous iliac artery dissection is not well defined. In fact, patients could be safely managed with medical therapy in the absence of signs of complications. Endovascular and open repair are reserved for patients with complications like limb ischemia or imminent artery rupture.

Key words: artery dissection; endovascular; vascular disease

\section{Introduction}

Spontaneous and isolated dissection of peripheral arteries without involvement of the aorta is an extremely rare event [1]. Renal, coronary, and pulmonary arteries are the most common involved arteries. Spontaneous and isolated dissection of the external iliacartery is an extremely uncommon event. Only a few patients have been reported in the literature [2].

The main etiologies include especially collagen vascular disease, pregnancy and intense exercises in athletes $[3,4]$.

Although several treatment options are available, including medical therapy, endovascular or open repair, there is actually no established consensus regarding optimal management

of spontaneous iliac artery dissection [5-7].

We report the case of a 44 years old patient with no history of vascular diseases or trauma who was admitted in our institution for a spontaneous dissection of the right external iliac artery.

\section{Case description:}

A 44 years old man, with no history of cardiovascular events or connective tissue disease, presented to our institution for a sudden onsetsevere painlocalized in theright iliac fossa.

The patient was in good general condition, apyretic, eupneic, blood pressure was normal at 120/60 $\mathrm{mmHg}$ and heart rate was 84 beats/minute.

The abdomen was soft and non-tender. The patient had no other systemic symptoms or signs. The lower limbs were warm, pulses were present but discreetly weaker on the right side. No signs of lower limb ischemia were noted.

At first, an abdominal ultrasound exam was performed and was perfectly normal. Then the doppler ultrasound exam showed signs of an isolated external iliac artery dissection with a false lumen's thrombosis and a patent true lumen without any hemodynamic impact (figure 1and 2).

CT scan was immediately performed and confirmed the doppler ultrasound findings and eliminated concomitant aortic dissection and signs of close rupture (figure 3 and 4 ). 


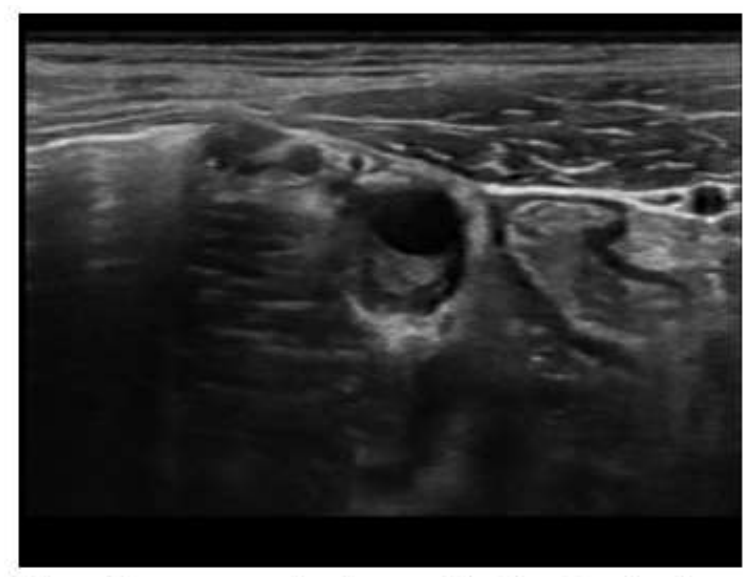

Figure 1 : transversal echographic slice showing the true and false lumen of the common iliac artery.

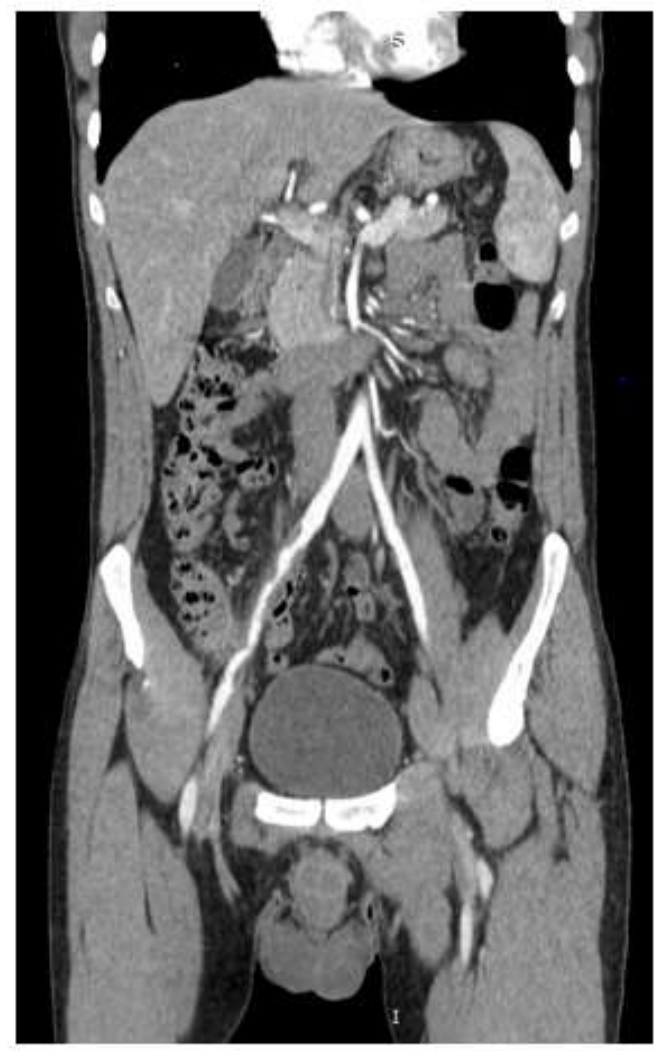

Figure 3: longitudinal CT showing the right common iliac dissection with occluded false lumen.

The patient was put under surveillance and received intravenous analgesic treatment and heparin at anticoagulant doses.

Due to the absence of rupture and limb ischemia signs the patient was put under intra venous analgesic treatment and heparin at anticoagulant doses. The evolution was marked bypain regression and absence of complications at day 4 of treatment so the patient was discharged.

The patient was reviewed one month later, the exam was perfectly normal and the patient was totally asymptomatic.

\section{Discussion:}

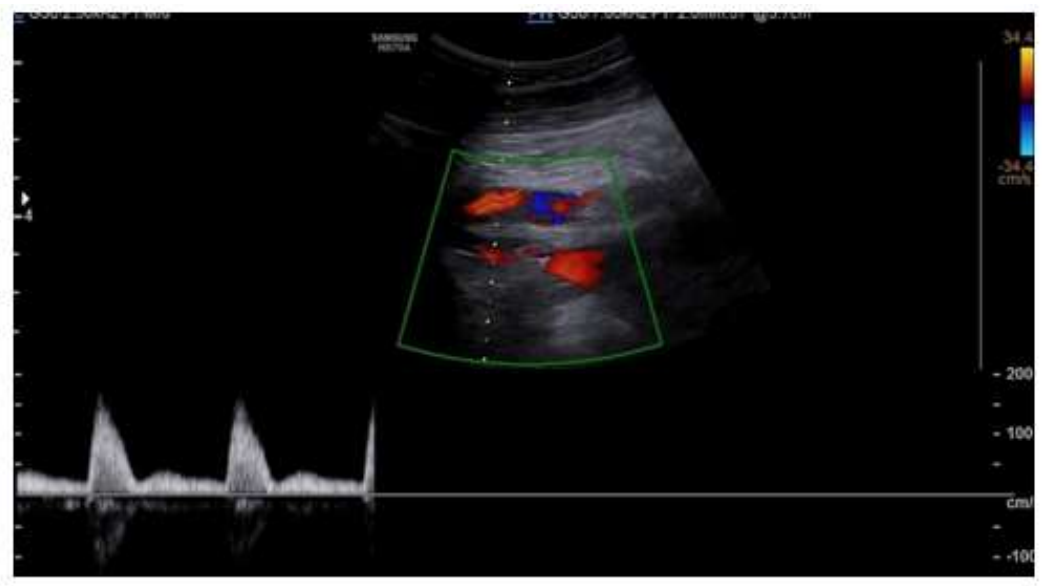

Figure 2 : patent commoniliacartery on doppler ultrasound.

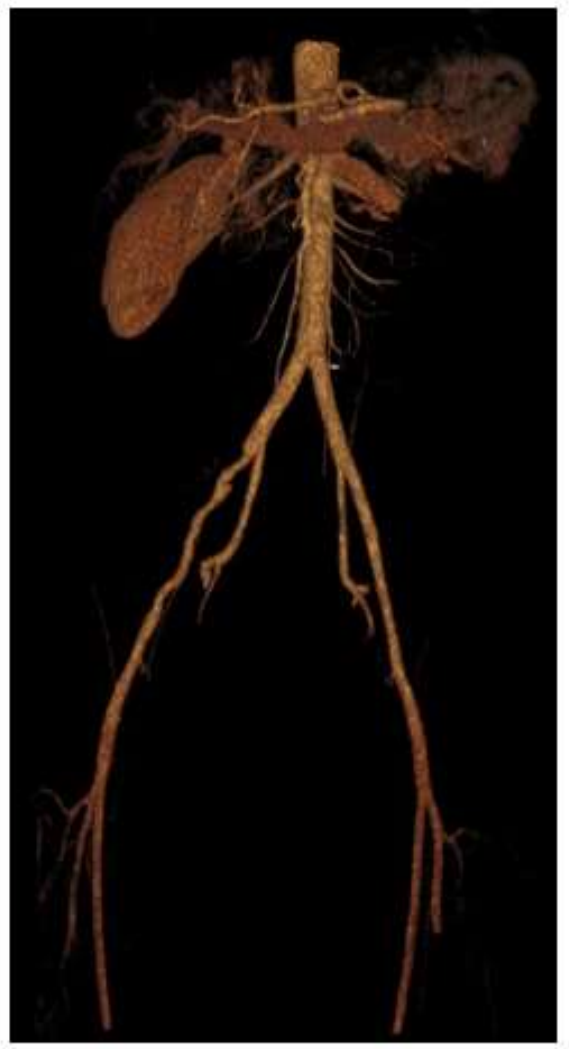

Figure 4: $3 D$ reconstruction of the aorta and ilio-femoral vessels showing right common iliac artery dissection.

The main etiology of spontaneous iliac arteries dissection is usually linked to connective tissue disorders, fibromuscular dysplasia and atherosclerosis. De Gallo et al reported a case of a highly trained biker, who presented with an external iliac artery dissecting aneurysm [8]. Cook and associates [9] also reporteda series of athletes who presented with external iliac artery dissection. These studiestried to explain the condition and suggested that the repetitive trauma due to hypertrophic muscles or adaptive hypertension of vigorous exercise may be the cause of dissection. The link between spontaneous iliac dissection and fibromuscular dysplasia is also well reported in the case reports of Luck, Patel and Burri [2,10-12]. 
The natural history of spontaneous iliac artery dissection is variable and unpredictable $[6,7,13]$. Even though, when stable, patients with spontaneous iliac artery dissection can beresolved spontaneously without specific treatment [14], but progress to true lumen occlusion, false lumen expansion, aneurysmal dilation, andartery rupture have been described in the literature $[6,7,13]$. The firstobjective of treatment is to limit the extensionof dissection, to maintain true lumen patency and blood flow, and to prevent rupture. several types of treatment are available such as conservative treatment, endovascular repair and open repair were reported $[6,7,13]$.There is actually no consensus or optimal management of spontaneous iliac artery dissection [15].

Liang et al. in their study reported that asymptomatic patients could be safely managedwith conservative treatment [16]. However, later follow-up is still not defined. These patients are at risk of aneurysmal degeneration which makes it necessary for them to undergo an annual check-up for screening an eventual aneurysmand its progression. In the other hand, Patients with symptoms like acute limb ischemia or rupture require emergency repair.

Endovascular repair has been reported as a treatment option for patients with spontaneous iliac artery dissection, it can be indicated or patients who failed medical therapy $[7,13]$. Although endovascular repair providesimmediate symptomatic relief and preventslater progression of the false lumen expansion [7,13], there aremany complications relatedto this type of approach, including stentrestenos is and occlusion of internaliliac artery. Open repair in also reported in the treatment of spontaneous iliac artery dissection [6]. These patients usually need an invasive laparotomy, complex reconstructions and even bypasses. The morbi-mortality rates are considered high with a long hospital stay after surgery. Endovascular repair became the preferred approach and made number of patients receiving surgery decreasing. However, open surgery maintains its place for complicated patients, patients with unsuitable or failed endovascular repair or patients with imminent artery rupture [16].

\section{Conclusion:}

Spontaneous dissection of the external iliac artery is a very rare that should be suspected in young patients presenting with ischemic symptoms and inguinal pain with no associated abdominal signs. Patients could be safely managed with medical therapy in the absence of signs of complications. Endovascular and open repair are reserved for patients with complications like limb ischemia or imminent artery rupture.

\section{References:}

1. Noh J, Rhee I, Kim M, Lee J, Kim K, Park B. A Case of Spontaneous Common Iliac Atery Dissection. Kosin Med J. 2018; 33(3):431.

2. Engin C, Calkavur T, Apaydin AZ, Durmaz I. Bilateral Spontaneous and Isolated Dissection of the External Iliac Arteries: Report of A Case. EJVES Extra. févr 2005;9(2):19-21.

3. Willson TD, Revesz E, Podbielski FJ, Blecha MJ. External iliac artery dissection secondary to endofibrosis in a cyclist. J Vasc Surg. juill 2010; 52(1):219-221.
4. Teh LG, Sieunarine K, van Schie G, Vasudevan T. Spontaneous Common Iliac Artery Dissection after Exercise. J EndovascTher. févr 2003;10(1):163-166.

5. Liang Z, Guo W, Du C, Xie Y. Effectiveness of the conservative therapy for spontaneous isolated iliac artery dissection: Preliminary results. Vascular. déc 2017;25(6):649-656.

6. Honjo O, Yamada Y, Kuroko Y, Kushida Y, Une D, Hioki K. Spontaneous dissection and rupture of common iliac artery in a patient with fibromuscular dysplasia: A case report and review of the literature on iliac artery dissections secondary to fibromuscular dysplasia. J Vasc Surg. nov 2004; 40(5):10321036.

7. Yoshida R de A, Kolvenbach R, Vieira PRB, Moura R, Jaldin RG, Yoshida WB. Endovascular Treatment of Spontaneous Isolated Common and External Iliac Artery Dissections with Preservation of Pelvic Blood Flow. Ann Vasc Surg. janv 2015; 29 (1):126.e9-126.e14.

8. Del Gallo G, Plissonnier D, Planet M, Peillon C, Testart J, Watelet J. [Dissecting aneurysm of the external iliac artery. An unusual course of endofibrosis in an athlete]. J Mal Vasc. 1996; 21(2):95-97.

9. Cook PS, Erdoes LS, Selzer PM, Rivera FJ, Palmaz JC. Dissection of the external iliac artery in highly trained athletes. J Vasc Surg. août 1995; 22(2):173-177.

10. Lück, Hanschke, Geißler, Gruß. Spontaneous dissection of the external iliac artery due to fibromuscular dysplasia. Vasa. 1 mai 2002; 31(2):115-121.

11. Burri B, Fontolliet C, Ruegsegger CH, Mosimann R. External iliac artery dissection due to fibromuscular dysplasia. VASA Z Gefasskrankheiten. 1983; 12(1):76-78.

12. Patel KS, Wolfe JH, Mathias C. Left external iliac artery dissection and bilateral renal artery aneurysms secondary to fibromuscular dysplasia: a case report. Neth J Surg. août 1990; 42(4):118-120.

13. Zha B, Zhu H, Liu B, Ye Y, Li J. Preservation of Internal Iliac Artery after Endovascular Repair of Common Iliac Artery Dissection Using Modified Fenestrated Stent Graft. Korean Circ J. 2016; 46(3):412.

14. Yoong S, Heyes G, Davison GW, Hannon R, O'Donnell ME. Spontaneous Dissection of the External Iliac Artery Secondary to Golf Club Manufacturing. Vasc Endovascular Surg. janv 2013; 47(1):73-75.

15. Sun J, Li D, Wu Z, He Y, Zhu Q, Zhang H. Morphologic findings and management strategy of spontaneous isolated dissection of the celiac artery. J Vasc Surg. août 2016; 64(2):389-394.

16. Liang Z, Guo W, Du C, Xie Y. Effectiveness of the conservative therapy for spontaneous isolated iliac artery dissection: Preliminary results. Vascular. déc 2017;25(6):649-656. 
(c) (†) This work is licensed under Creative Commons Attribution 4.0 License

To Submit Your Article Click Here: Submit Manuscript

DOI:10.31579/2692-9392/070
Ready to submit your research? Choose Auctores and benefit from:

* fast, convenient online submission

* rigorous peer review by experienced research in your field

* rapid publication on acceptance

* authors retain copyrights

* unique DOI for all articles

* immediate, unrestricted online access

At Auctores, research is always in progress.

Learn more www.auctoresonline.org/journals/archives-of-medical-casereports-and-case-study 